\title{
Combining Family and Building a Successful Career for a Russian Woman Today: Myth or Reality?
}

\author{
Miroshnichenko Olga \\ Evgenia E. Frolova
}

Tatiana Samusenko

Law School, Far Eastern Federal university, Vladivostok, Russian Federatio

Doi:10.5901/mjss.2015.v6n5s2p102

\section{Abstract}

The author analyses the difficulties a woman in modern Russia faces when she tries to combine family and building a successful career making. The author comes to the conclusion that the full-fledged combination of a career and family responsibilities for women in Russia is quite possible today. This fact is evidenced by the experience of many Western countries. However, it requires serious changes in the mass consciousness and a fundamentally different state policy in the field of family and childhood. Society should not chase a woman into a corner with stereotypes about her natural mission.

Keywords: Gender, career, women's rights, family, natural mission, stereotypes

\section{Introduction}

In the modern sense, 'career' is a particular mean of finding yourself, your own way. On the one hand, it means that a person can realize herself/himself, and on the other hand that her/his work is highly regarded by others.

A career as one of the strategic directions of life reflects our attitude to self-fulfilment, self-improvement, and creative self-expression.

Considering a career in a woman's life, we should first note the complexity and many-sidedness of the importance that it has for the woman, because often when building a career Russian women have to choose between the achieving in professional activities and having a family. Every woman presented with this dilemma faces a number of difficulties, depending on the choice she makes.

\section{Research Methodology}

The study is performed by using the statistical method, as well as the comparative legal analysis method. In the concluding part, methods of forecasting and research hypotheses are used.

\section{Results and Discussion}

Actually, the whole the story of human civilization is a story about women shouting: 'We are people too!' We can divide so-called 'women's history' into four main periods:

1. Women are the main people in the community. They, and not the men, keep the hearth fires burning, they are those by whom a family is established. A period of matriarchy, the period not all scientists believe in.

2. People invent work tools and start working the land; the Neolithic revolution happens. Physical strength is now much more important, a man is the one who creates goods and by whom families are counted.

3. A very long period of women being almost 'owned' by their men. A woman belonged to her man and didn't have any rights. Numa Denis Fustel de Coulanges, one of the well-known modern historians, talks about religion in his treatise about ancient civil communities He states that religion was the most important part of life for ancient peoples. A person was considered as a person only because of his belonging to family religion. And no woman could be a part of the religion. She was allowed to be located in the house, near the hearth where the family God was living, only because she belonged to her husband or father. (Numa Denis Fustel de 


\section{Coulanges)}

4. And the last period of modern civilization that started at the end of the nineteenth century in Great Britain with the so-called 'Suffrage Movement'. Women insisted on the right to vote and to stand for electoral office. Later, at the beginning if the twentieth century, special international organizations were created to coordinate efforts to gain equal civil rights for women. This was also a very difficult period. Those women were called mad, and many men even hated them. It was a very exhausting and long fight... The first country to give women their rights to vote was New Zealand, in 1893. And only by the end of the twentieth century (!) did all women in all civilized countries get their civil rights.

But this was still not the end. Women had gained their legal rights but not the moral possibility of being a person. In 1873 Harvard's professor, Edward Clarke, asserted that women should not be allowed to attend college. If young women studied too much, they would divert blood away from the uterus to the brain, rendering themselves 'irritable and infertile' (education.com). In some countries women were obliged to ask a husband for the permission to work until the middle if the twentieth century. And even today, when more than 50 per cent of students all over the world are women, nine countries are led by women, including conservative Germany (http://m.forbes.ru/article.php?id=64542), even now many men do not allow women the moral right to get an education, a good job and still have the time and ability to be a mother and a good wife. Society often makes a woman choose between career and family, even if it is not necessary.

One of my friends, at the time of employment as a chief accountant in a private firm, had to sign a humiliating agreement binding her not to give birth within five years. This agreement was contrary to all labour laws, however, it had a crucial impact on her destiny: this woman fulfilled the employer's condition against her husband's will, who wanted to have children. The conflict led to divorce. My friend remained working as a chief accountant. Then she moved to another company where there was even more work, and the prospects were even better. Family and children simply did not fit into her lifestyle. Now she is 45 years old, not married, and it is too late to have children. Almost all her time is spent at work; she earns a lot, holidaying at prestigious resorts, and can afford expensive things and jewellery. Many people are jealous of her. She does not depend on anyone. She has friends and acquaintances, but almost all of them are busy with their families and businesses. Love stories happen with men, but less and less. 'Age,' she sighs, and sits down to write the next work report. She feels no regrets, but admits that sometimes gets lonely and depressed.

So, family and career: can they be combined? This question is still relevant for many women in Russia. Men do not wonder about such things. Career for them is a significant, often major, component of their lives. And society never argues about it. For employers, a man who has a family is a most suitable candidate. It is believed that he can be trusted more than a bachelor can. With women, it is quite different. Employers consider having a family, and especially children, as a burden, fearing that they will be given more attention than the work (http://www.ng.ru/economics/2011-0719/1_gender.html). Such fears are largely justified: household chores, and children's illnesses do not allow a woman to fully prove herself at work. Families in which a woman earns more than a man do occur. However, this situation rarely satisfies both spouses. Socially active women tend to prefer a partner who iss more successful than they are. Moreover, the husband suffers being in the dependent role. Men do not sacrifice career for love or family, but seek opportunities to save them both. Extremely rarely men discontinue working or reduce work 'for family reasons'. This is women's duty. Women are sometimes faced with a tough choice, not only by employers but by their family members as well. In case of conflict, they usually have to choose one or the other.

How often is their choice in favour of a career? According to social opinion polls, about $80 \%$ of women choose family and children, $12 \%$ choose a career, $8 \%$ find it difficult to choose. Home, family, and children still remain the main choice. This does not mean that women do not work at all. Very few women can afford to be only a housewife: in our society, not all men are capable of supporting a family. Besides, a woman often likes to have her own earnings, however small, in order to be less dependent on her husband. Women also want to feel that they benefit society. However, they do not make a career that involves irregular hours, frequent business trips, sustained professional advancement and upward career moves. Many (both women and men) believe that a woman's choice in favour of the family proves her natural destination is to be a mother. Some (mostly women) think that career is more important, because it gives them the opportunity to be independent, opens the way to creative and professional self-realization. A few optimists (mainly young people) believe that it is possible to combine both family and career in full.

Most psychologists argue that in today's Russia, a woman's attempts to combine full dedication to a professional field with family responsibilities have a negative impact on her. Namely, a woman who works excessively has a 'dark side to her soul', some deep psychological problem. It may be a feeling of guilt regarding her children, who do not receive all the warmth of maternal feeling, or the inability to have a close relationship with a man because she does not have enough mental strength for one. The desire to combine a successful career and family leads to chronic fatigue, which leads to no desire in life at all. A woman holding a senior position often feels that achieving her career was made too 
difficult. This hardens her; she becomes, as they say, "a'bitch'.

Today, two poorly compatible stereotypes successfully coexist in the mass consciousness: 'the main thing for a woman is home and family' and 'it is possible to build a successful career and simultaneously be a good wife and mother'. The first stereotype has roots in the patriarchal system of values, in which there is a strict division of roles: a man is an earner and a woman is a housekeeper. Patriarchal moods are still strong in Russia, which explains the popularity of this stereotype.

The myth of the successful combination of career and family originated in the Soviet era, confirming the equality between genders launched after the Revolution. However, in reality this equality turned to be a double burden for a woman: at work and at home, an extremely unsettled way of life. Since the end of the last century, this myth has been intensively promoted by the mass media in movies, TV shows and advertising. Accomplished businesswomen make a career, have a tender husband and happy children. On the one hand, latterly women have really started to prove themselves' in the professional field - the number of leading women has increased. However, to make sure this process does not go too far, there is another, parallel, operating stereotype persuading the successful woman that her main purpose is to be a wife and mother. 'I'll try to combine them,' she thinks, but she only understands just how difficult this is when she tries. And she may not understand, and may blame herself that it is she who is incapable of doing this, that she has little force, or that she is just a bad mother.

With these polar stereotypes of mass consciousness, society regulates demographic policy (a woman, regardless of her social status, still needs to be persuaded to give birth), and, at the same time, controls women's social activity (a woman must work, but not in key positions).

\section{Conclusion}

Every woman by herself should make her own choice in accordance with her personal skills, preferences, circumstances of life. However, the possibility of such a choice depends heavily on what kind of economic and moral support will be given by the state and society on each of the selected ways. The author believes that the full-fledged combination of a career and family responsibilities for women in Russia is possible. This fact is evidenced by the experience of many Western countries. However, it requires serious changes in the mass consciousness and a fundamentally different state policy in the field of family and childhood. Society should not chase a woman into a corner with stereotypes about her natural mission. Equality of roles in the family should be intensively promoted. A man taking medical leave for child care in Russia, should not be looked at as 'black sheep', being the object of colleagues' mockery and causing indignation among his superiors. The policy of small companies and large enterprises should be built in the spirit of intolerance for discrimination against women. In addition, a system of affordable child-care institutions, with highly qualified personnel, is required. Without such changes stereotypes will remain either as a brake on female social activity, or as an - in reality unavailable ideal in which, while trying to achieve it, a woman will only waste her physical and mental health.

\section{References}

Gender salary unfairness (link) //URL:http://www.ng.ru/economics/2011-07-19/1_gender.html

(http://m.forbes.ru/article.php?id=64542

Numa Denis Fustel de Coulanges. La Cite Antique.

Education.com

http://www.ng.ru/economics/2011-07-19/1_gender.html 